This is an Author's Accepted Manuscript of an article published in Islam and Christian-Muslim Relations, Vol. 23, No. 3 (2012) p. 347-362, Version of record first published: 22 June 2012 Taylor \& Francis@, available online at: http://dx.doi.org/10.1080/09596410.2012.676782

(Access to the published version may require subscription)

[vrh]A.S. Roald[/vrh]

[rrh]Islam and Christian-Muslim Relations[/rrh]

[fn]Email AnneSofie.Roald@cmi.no[/fn]

\title{
The conversion process in stages: new Muslims in the twenty-first century
}

Anne Sofie Roald

Chr. Michelsen Institute, Bergen, Norway.

This study deals with stages in the process of conversion to Islam. However, unlike the extensive research on pre-conversion stages, this contribution looks at post-conversion development. The initial stage after conversion brings with it a zealotry in which converts tend to become 'more royal than the king'. The second stage tends to be a period of disappointment with the new peer-group. The third stage is one of acceptance, when converts accept that Muslims are 'ordinary' human beings with shortcomings rather than saints who manage to totally live up to the 'ideal' of Islam. The fourth stage is one of secularization, when converts tend to adopt a private religious attitude to the religion. This stage is to a great extent linked to the post-9/11 situation, in which many Muslims feels targeted as potentially terrorists, but it also reflects the extent to which converts integrate into Muslim communities. Some converts continue to practise religious precepts in this fourth stage, while others leave their religious practice and become non-practising Muslims.

The stages in the conversion process are also discussed in terms of Susman's modal types of 'character' versus 'personality'. Converts tend to adopt the modal type of 'character’ as they embrace Islam. In the fourth stage, however, converts tend to return 
fully to the modal type of 'personality', the modal type into which most of them were socialized.

Keywords: Islam; convert; new Muslims; conversion process; conversion stage

\section{Introduction}

In the nineteenth and the beginning of the twentieth century, it was rare for Westerners (people from Europe, the USA, Australia and New Zeeland) to convert to Islam. The few who did were individuals who in one way or another had come into contact with the Muslim world. The British convert Muhammad Pickthall (1875-1936), who published the well-known translation and commentary on the Qur'ran, The Meaning of the Glorious Koran, in 1930, is one example and the Swedish painter Ivan Aguéli (1869-1917), who converted to Islam by being initiated into the Shadhiliyya Sufi order in Cairo in 1902, is another (Gerholm 1988). Some even built up convert communities in their hometowns; an example is William Henry Quilliam (1856-1932), who founded the Liverpool Muslim Institute in 1889 (http://www.muslimnews.co.uk/hmosque102.html).

As Muslims started to settle in Western countries from the mid-twentieth century onwards, conversion to Islam increased. Up to the 1990s, it was to a great extent linked to personal encounters between Muslim immigrants and Westerners, and the 'love'-theme, with mainly women, but also some men, falling in love with immigrant Muslims, was an important variable (Roald 2004, 95-100; Allievi 2006, 122). However, some converts, particularly Sufi adherents, have embraced Islam because of Sufism's emphasis on spirituality and not necessarily as a result of love encounters. Moreover, the gender imbalance in convert communities, with its initial preponderance of female converts, has changed from the 1990s onwards, with increasing numbers of male converts.

One might have assumed that the perception of shocking images of fanaticism and violence as equivalent to 'Islam', and the ongoing 'war on terror', which is closely linked to Muslim extremism, 
would have impeded conversion to Islam. This assumption has not proved true, however. In USA, for instance, conversion to Islam increased after 9/11 (Haddad 2006, 19-20; $44 \mathrm{nn}$. 2-3). Interviews with Muslim leaders in Scandinavia indicate a similar trend. So new converts may be on the increase, but in the old convert community there seems to be a change in attitudes towards 'Islam' and the born-Muslim communities, mainly as a result of Muslim terror activities. The present study will deal with stages in the process of conversion in the era of 'the war on terror', on the basis of interviews with Islamic leaders and Western converts on the one hand, ${ }^{1}$ and literature, web-pages and newspaper-articles on the other.

\section{The convert stages}

Historically speaking, religious conversion in Christian contexts has been studied in a wide range of academic fields, including theology (with various theological studies on the conversions of Paul and Augustine, such as James 1903; West 1933), psychology (Starbuck 1901; James 1903) and sociology (Lofland and Stark 1965). Researchers started to focus on Muslim converts from the 1980s onwards (Gerholm 1988; Poston 1992; Köse 1996). There was a tendency in this early research to view Muslims’ conversion experiences as following the pattern of conversion to Christianity (Månsson 2002, 41), but at the turn of the century research on the process of conversion to Islam has tended to see this experience as unique to Muslims, although researchers tend to accept similarities between conversion processes in various religious traditions (Månsson 2002; Roald 2004; van Nieuwkerk 2006).

In general, a convert's way into a new religion has often been regarded as a process of stages (see particularly Rambo 1993; Rambo and Farhadian 1999). However, whereas Rambo mainly deals with stages before conversion, Werner (Catholicism) and Roald (Islam) discuss stages in the conversion process after conversion has taken place (Werner 2010; Roald 2004; 2006). The Danish convert and priest, Peter Schindler (1892-1967), wrote a handbook for converts to Catholicism, in which he speaks of the psychological stages through which converts pass after conversion (Werner 
2010). The first stage is described in terms of enthusiasm which, in a second stage, leads to boredom. According to Schindler, in order to overcome this 'dangerous' second stage, the convert should submit to the commands of the Church and fulfil his or her obligations to the Church, and thereby reach the third and last stage, which is that of 'mature' religiosity (Werner 2010). I have discussed elsewhere the three stages in the new Muslim's conversion process after conversion in similar terms to those used by Schindler (Roald 2004; 2006). The present study discusses the conversion process in the post-9-11 era in four stages, building on the three stages previously elaborated by Werner and myself.

The four stages in the Muslim conversion process are to a great extent associated with new Muslims’ relations to the born-Muslim community. The stages may be named: ‘zealotry’, 'disappointment', 'acceptance', and 'secularization'. The four stages should be considered in light of Weber's ideal type-model indicating a 'typical course of conduct', which can work as 'an analytical construct' (Coser 1977, 223-4). The stages are thus abstractions of social behaviour rather than absolute images of reality. As an abstraction, each stage represents a cultivated model of reality, although each stage in a convert's conversion process may also include aspects of the surrounding stages. Moreover, not all converts go through these stages, and not all go through them in the same order. The stages in the conversion process are therefore not static (Roald 2006).

The stages in the conversion process may be further analysed alongside Susman's notion that 'changes in culture do mean changes in modal types of character' (Susman 1979, 225). Susman sees a shift in 'modal type' in the Western world in the early twentieth century from that of 'character' to that of 'personality'. By 'character' Susman means a modal type acting according to 'a group of traits believed to have social significance and moral quality' and 'a standard of conduct that assured interrelationship between the "social” and the "moral”' (ibid., 214). By 'personality’ Susman means a modal type acting according to 'personal needs and interests' and he sees the change of modal type from 'character' to 'personality' as a result of the vision of self-sacrifice beginning 'to yield to that 
of self-realization' (ibid., 217). In light of Susman’s theory, Otterbeck has observed that Islamic scholars stress the modal type of 'character' (Otterbeck 1999, 165). Many Muslim immigrants in Europe come from countries where social cohesion is built mainly on family ties and where individual behaviour is built on a standard of conduct (ibid., 165; see also Susman 1979). The Muslim cultural sphere converts are faced with is therefore mainly one of 'character', a modal type opposed to that of 'personality' into which many converts to Islam are originally socialized.

\section{The first stage: 'zealotry'}

I have previously named the first stage of conversion the stage of 'falling in love' (2004: 283-284). The term 'zealotry' (or 'enthusiasm', to use Schindler's term) is, however, more applicable in the polarized era of 'the war on terror'. Although this stage seems to be a general convert phenomenon, as also indicated by Schindler's observation of Catholic converts, it is particularly visible among Muslim converts because of the growing tension between Islamic exclusionist and inclusionist understandings on the one hand, and between Islamic extremism and 'the West' on the other. This convert stage of 'zealotry' is marked by the new convert distancing herself or himself from old peergroups and becoming totally absorbed into a new world-view; the convert making a total shift from one cultural sphere to another. In the Islamic context, this shift in intellectual outlook and social loyalty is mainly due to the pervasive Islamist conception of 'Islam as a way of life'. As many new converts adopt this perception they tend to incorporate born-Muslim cultural traits as they embrace Islam. Susman states that 'changes of culture do mean changes in modal types of character' (Susman 1979, 225), and it is thus possible to see converts at this first stage as turning from the modal type of 'personality' to that of 'character'; i.e. they want to merge the social and the moral and they try to follow the standard of conduct depicted by the Muslims with whom they socialize. As Schindler indicates, this is also a common trait among converts to Catholicism (Werner 2010).

This first stage, of total acceptance of and engagement in a new religious and cultural context, would in most cases automatically involve a rejection of the socio-cultural sphere in which the 
convert is born and bred. Many Sufi converts are traditionalist in the sense that they adhere to the Islamic law-schools. This form of Sufism, as well as the salafi understanding of Islam, stress the importance of 'believers' distinguishing themselves from non-believers. Furthermore, many female converts said in the 1980s and 1990s that they were requested by their born-Muslim husbands to reject their previous behaviour, cultural norms and social networks, probably as a result of Muslims being a minority and thus feeling threatened by majority society (see Roald 2006). Thus, many new Muslims tend to respond to this request by separating themselves from their previous intellectual and socio-cultural environment. Eva tells of how she, as a newly converted Muslim at the end of the 1980s, wanted to follow all Islamic rules and injunctions from day to day. She explains:

How could I know at that time that most of what I learnt about Islam was based on a cultural understanding of what Islam is? My greatest wish at that time was to be a 'good' Muslim. Islam was everything to me. How could it be anything else? I would never ever even have contemplated embracing Islam if I did not believe it to be superior to any other religion. And Islam was, I was told, 'a way of life'.

Nock, in his study on Christian converts in the early Christian era, has also observed that converts tended to distance themselves from their original cultural and religious sphere, claiming that this 'aversion' to or rejection of the convert's previous religious context was an important element in the conversion process (Nock 1998).

The initial phase of conversion, with separation from former peer-groups and the 'more royal than the king' attitude of 'zealotry' common for converts to various religions (Roald 2004), is evident in most of the new Muslims' discussions. Similarly to Eva, many new Muslims tell of how, in the beginning, they tended to be emotionally obsessed with the new religion and wanted to practise every little detail of the Islamic precepts. Kari, who embraced Islam in her late twenties in the mid-1980s actually used the term 'fanatic' as she described herself in the early phase of the conversion process as wanting to throw out the television set and thinking of wearing a face veil. 
This 'zealotry' in the first stage of a post-conversion process is also, as indicated above, a phenomenon in the process of conversion to Catholicism and other religions.

The phenomenon of absolutism seems to be universal among new converts to Islam. A leading British academic convert, 'Abdal-Hakim Murad ( Tim Winter), has termed the phenomenon 'convertitis', describing it as a tendency among new converts to create a strong 'Them versus Us' paradigm where everything within the circle becomes 'angelic' and everything without it becomes ‘demonic’ (Murad 1997). The American convert, Saraji Umm Zaid, elaborates on Murad’s term 'convertitis', which she sees as a 'highly contagious disease, which spreads rapidly among converts to Islam'. She also refers to the phenomenon as 'insta-scholar', giving the example of 'the Instascholar Jane who took her shahada (the profession of faith, i.e., embraced Islam) last week’ and suddenly changed radically in appearance and behaviour from one day to another (Umm Zaid 2003).

There is an obvious link between converts in the first stage of conversion and many Sufi converts who adhere strictly to the rules of the Islamic law-schools, as well as adherents of salafi movements; their strict exclusionist attitude and attempt to behave 'Islamically' in every little detail of life are significant similar traits. As for the salafists, the now defunct Swedish website www.muslimer.com, which was run by female converts to Islam, illustrated the link between salafism and new converts' 'zealotry'. The articles posted there dealt with women's total submission to male authority and emphasized female covering and seclusion from men (Roald 2004, 155-7). Many of the women who ran the website had close links with the jihadi trend within the salafi movement (ibid., 155-8). One, for example, lived with her Algerian husband in Afghanistan for some years. During the USA’s bombing of Afghanistan in autumn 2001, the Swedish newspapers reported her missing. In the pre-9/11 world, the people behind this webpage kept a low profile and it no longer exists.

Apart from a few introductory statements, all the material on the site was translated from texts written by salafist scholars, such as Muhammad ibn 'Abd al-Wahhab (d. 1787), Sheikh Nasr al-Din 
al-Albani (d. 1999), Muhammad S. al-Munajjid, and Abu Hamza al-Masri (the latter tried and imprisoned on charges brought in UK courts). The introductory texts indicated a 'convertitis' approach, referring in harsh terms to non-Muslims and Muslims of other denominations. al-Masri wrote for instance on the duty of women in to be good and decent wives: 'For a young woman to go out and learn how to command men, have a career like a man and be independent, is bad, and the result is that the woman is neither a woman nor a man.' Another female duty promoted by al-Masri on the website was the education of her children. He said that a Muslim woman should not send her children to places where they might lose their religion. 'To give them knowledge,' he says, 'does not mean that they should be sent to school.' A text that discussed women and travelling, promoted the view that women should never travel without a male relative (mahram) even if the journey only took a few hours. The salafi ideology includes encouraging gender segregation in society, as promoted by many of the other texts on the website. By segregating themselves from non-Muslims and Muslims of other ideological stands, salafists consider that they will reinforce and reproduce the salafi ideology within the group with little influence from the outside world.

Similar ideas, although expressed in less absolute terms, are also found in some communities of Sufi converts, such as followers of Nuh Ha Mim Keller and Hamza Yusuf. The texts discussed above, as well as texts by Keller (e.g. Keller 1991) and speeches by Hanson (Roald 2004, 223-9), particularly before 9/11 2001, when he made angry statements about Jews and America (O’Sullivan 2001), are indicators of the modal type of 'character' incorporated in some Sufi trends and in the salafi ideology, with specific rules and a standard of conduct that dictate how to become a 'good' Muslim.

It is also interesting to note that al-Masri himself is a sort of convert. He was indeed born in a Muslim family, but stories about his first years in Britain witness that he was not living a life according to the tenets of Islam. His later 'zealotry’ might therefore be regarded in terms of a conversion from being a Muslim to becoming an extreme Islamist. Some Western converts have also 
been engaged in terrorist activities, such as the 'shoe bomber' Rickard Reid, Germaine Lindsay, one of the suicide terrorists in the 2005 London bombings, and Colleen LaRose, known as 'Jihad Jane'.

Most converts tend to move on from this first stage of 'zealotry'. However, some remain in this stage and the two main variables for remaining are: first, the Islamic orientation of the spouse and, second, the degree of participation in majority society. The tendency to follow the spouse is linked to the converts' wish to become 'good Muslims' and acceptance of the spouse's cultural and religious norms as the 'right Islam'. As for the degree of participation in majority society, converts who work alongside non-Muslims seem to be more inclined to leave the stage of 'zealotry' behind, whereas new Muslims who work at home or in Muslim organizations or who live in Muslim countries for a length of time seem to be more apt to remain in the first stage (Roald 2004). One prominent example of a convert who has remained in the first stage of conversion is Bilal Philips, a prolific writer of Islamic books. I note (Roald 2004, 213) that his books are widely read by converts who have recently converted to Islam, whereas those who converted a long time ago tended to reject Philips’ exclusionist approach with its exclusion of those who do not accept this 'one truth'. This rejection of Philips’ absolutism reflects changes in attitude at different stages of the conversion process. The exclusionist approach is common in the initial stage of conversion, when the individual rejects his/her former identity.

\section{Bilal Philips}

Bilal Philips, born 1947, is of Jamaican background; he was brought up in Canada and embraced Islam in 1972. His main educational background is from Saudi Arabian universities, although he has a PhD from Lampeter College, University of Wales. His Islamic approach is mainly based on Wahhabi or salafi thought, although in interviews and on his homepage, Philip deliberately avoids to call himself a Wahhabist or a salafist. For most of the time since his conversion, Philips has lived in Muslim countries and been associated with Islamic institutions that have a salafi stance, which has 
probably influenced his approach to Islam and his remaining in the first stage of the conversion process.

His salafi approach is particularly notable in his stand on Hadith, which he interprets literally, in the manner of prominent salafist scholars. His theological position, both in relation to the nature of God and the practice of Islamic rules and regulations also indicate a salafi orientation (Philips 1990, iii-iv; 14).

In the middle of January 2007, the British Channel Four broadcast a documentary called 'Undercover mosque’ (in the 'Dispatches’ series) based on sequences secretly filmed at meetings at UK mosques during 2006 with various Muslim preachers, including Philips and the American convert Abu Usamah (Channel Four). In the documentary, Philips is accused of promoting the practice of marrying girls before they reach puberty on the grounds that the Prophet himself married a nine-year-old girl. Philips claimed that he had been misunderstood and that his statements were taken out of context. As he writes on his homepage www.bilalphilips.com, 'the whole documentary seems composed out of bits and pieces of recordings taken out of context.' In his defence against the accusation of permitting sex between old men and young girls under the age of puberty, which according to the British legal system is well under the age of consent, he states that what he actually did was to defend the Prophet Muhammad's marriage to a nine-year-old girl. In seventh-century Arabia, according to him, marrying young girls as they entered puberty was a common custom and it was not uncommon in Arabia at that time for girls to reach puberty at the age of nine. To reinforce his view that sex under the (British) age of consent is not at all problematic, he referred to the case of Holland, claiming that the age of consent there is 12 [which is not true]. His conclusion is that, according to Islam an older man may well marry a young girl, if she has reached puberty, but residents in the UK must follow the laws of the country, which means that marriage cannot be entered into unless both parties are over 16 years old - the age of consent. 


\section{Abu Usamah}

The other convert who was 'unmasked’ by Channel Four goes under the name of Abu Usamah and is a preacher at a mosque in Birmingham. Abu Usamah is an African-American who was born in New Jersey in 1964 and converted to Islam in 1986. Like Philips, he was educated at a Saudi Arabian university; he has lived and worked mainly in Muslim communities in the USA and the UK, and has a salafi approach to Islam. In a video made in response to the Dispatches programme (islamictube.net), he claims, like Philips, that his statements were taken out of context. However, he admits that some of the statements criticized in the programme were adequate and according to the teaching of the Qur'an and Hadith. The statement to which the television programme drew particular attention was: 'Allah has created the woman - even if she gets a $\mathrm{PhD}$ - deficient. Her intellect is incomplete, deficient. She may be suffering from hormones that will make her emotional.’ In Abu Usamah's response he claimed that he had not spoken wrongly as the clear message from the Qur'an and Hadith is that women are deficient in intellect, referring to a hadith in which Muhammad is related to have said: 'I have not seen anyone more deficient in intellect and religion than you.' (alBukhari n.d., see ‘Book of menstruation’, no. 293; 'Book of almsgiving’, no 1369). Salafists and many new converts tend to have such views on women, reading the Qur'an and Hadith literally (Roald 2001). As the Qur'an and Hadith, like the sacred texts of the other monotheistic religions, contain passages that reflect the cultural context of the time of their origin, a literal reading will necessarily lead to a gender-biased attitude being the 'true Islamic' stance.

Philips’ and Abu Usamah’s way of arguing indicates the link between the salafi and the 'convertitis' approach as the first stage of the conversion processes. Some new converts' involvement in terror activities, which is linked to a great extent to certain trends within salafism, indicates the connection between salafi ideology and the first stage of 'zealotry' in the conversion process. There are many salafist websites and new Muslims, in their 'more royal than the king' approach, tend to end up reading them, as well as salafi literature. However, although many converts 
develop their Islamic ideas and thought through a conversion process of various stages, in interaction with Muslims of various opinions and with non-Muslims, some, such as Philips and Abu Usamah, remain in the first stage, despite having being Muslims for more than 20 years. The effect of the convert's working and living environment on the conversion process seems a probable factor in both cases, as Philips lives and works in the Arab Emirates and Abu Usamah is working within Muslim communities in the Western world.

\section{The second stage: 'disappointment'}

According to my observations, the second stage of 'disappointment' seems to pass rather quickly, and it will therefore be explained briefly.

After a while, when the first 'intoxication' has worn off, many new Muslims realize that they have bitten off more than they can chew. All the new rules and regulations that they want to introduce into their life may be felt to be too much. Schindler's discussion on the second stage of the Catholic conversion process, indicates that the convert, due to his or her zealotry in the first stage, is particularly receptive to 'convert germs', in the form of boredom, resignation and a critical attitude (Werner 2010). In the Muslim context, this critical attitude typical of the second stage of the conversion process is directed at born-Muslims' behaviour. At first, there is a tendency among new Muslims to look at the cultural Muslim expressions as ‘the true Islam'. After reading books and having discussions with other Muslims, many realize the difference between Islamic ideals and Muslim behaviour, as well beginning to appreciate that there are a multitude of 'true Islams'.

This second stage of the conversion process is therefore strongly linked to disappointment with born-Muslim behaviour and ideas. In my discussions with new Muslims, many of them described how they started to judge Islam by Muslims’ behaviour, and suddenly realized that Muslims do not live according to lofty Islamic ideals. The British convert Michael A. Malik illustrates this disappointment with born-Muslims when he writes: 
Islam is wonderful, but I can't stand the Muslims. Why should I try to convert my non-Muslim friends when I often prefer them to the Muslims that I know? How will being Muslim change their lives for the better if they already display more of the Islamic virtues than most of the Muslims they are likely to meet? (Malik n.d.) At this stage, some new Muslims tend to withdraw from the born-Muslim community and turn towards the convert community, where they 'feel more at home', as many converts expressed it. Some even turn away from Islam at this stage as they feel disappointed with their new belief group. Some however move on to a third stage.

\section{The third stage: 'acceptance’}

The third stage is when the new Muslim realizes that Muslims are 'human beings and not supernatural creatures', and comes to accept intellectually 'the discrepancy between ideal and reality’ (Roald 2004, 285-6). At this stage many new Muslims tend to search for new understandings of Islam, particularly those suitable to the cultural context in which they live. This stage may be called the stage of 'acceptance' (cf. Schindler's term 'maturity'), as many new Muslims have stated that they feel they have come 'back to themselves'. However, while the Catholic converts Schindler discusses have the central Catholic message to relate to, Muslim converts are faced with various Muslim cultural communities as well as a multitude of Islamic orientations. Which direction the convert chooses is decisive in his or her further religious development. Whereas in the first stage converts tended to shift from the modal type of 'personality' to 'character', in this third stage the notion of coming 'back to themselves' may indicate a shift in the opposite direction, although they would still be in a modal type of 'character' to a certain extent; it is important for them to be 'good Muslims' and in that sense they follow the Islamic standard of conduct and morality promoted by the Muslims with whom they socialize.

This notion of coming back to oneself; being both European and Muslim, is illustrated by Østberg's concept of integrated plural identities (Østberg 2006). Notions of cultural and religious 
shifts and integrated plural identities are linked to the question: how does one maintain a particular religious world view in a different religious context? Berger and Luckmann speak in terms of plausibility structures: a religious person develops the plausibility structure necessary for the maintenance of 'a symbolic universe' (Berger and Luckmann 1967). Hamberg, has considered how a person’s plausibility structure might be disrupted by migration. She discusses various factors in the migration situation and concludes that, because an immigrant tends to lose contact with her/his own group or with like-minded individuals, it might be difficult to maintain belief in her/his original 'symbolic universe', as s/he is not surrounded by a supporting structure that makes this belief plausible (Hamberg 1999, 27).

Hamberg's discussion of immigrants’ plausibility structures can be applied to new Muslims’ situations. As 'religion' in many Muslims' understanding of Islam involves not only belief but also a complete symbolic universe, the shift to a new belief must incorporate a new plausibility structure. The influence the new plausibility structure has over the new Muslim depends on his/her life situation. If the new Muslim is living in an environment comprising only born-Muslims from one particular cultural background, the Muslim plausibility structure has a stronger effect on him/her. However, a Muslim convert who has less contact with born-Muslims and more contact with nonMuslims will be less influenced by the plausibility structure to which s/he belongs religiously. A third alternative is more common: new Muslims of similar cultural backgrounds mix and create a merged plausibility structure built mainly on Islamic precepts but mixed with the new Muslims’ preconversion cultural context. In this case, it is possible for new views and ideas to emerge, built on the deconstruction and reconstruction of cultural concepts from both the majority society and Muslim cultural contexts.

\section{Hamza Yusuf}

In order to illustrate the stage of 'acceptance' I will refer to the experience of the American convert, Hamza Yusuf of the 9/11-event. Yusuf is an imam in a Muslim congregation in California. He is 
well-known as Sufi traditionalist preacher throughout the Western world. Yusuf became Muslim in 1977 at the age of 17 and his Islamic educational background was in Mauritania, where he lived for many years. Since returning to the US, Yusuf has worked mainly within the Muslim community. The traditional Islamic law-schools were formed in the early period of Islamic history, and so the laws and regulations within the law-schools are to a great extent based on the social context of traditional society. However, traditionalists, although they uphold in general the values of traditional society, they differ from salafists in that they do not set up absolute barriers between Muslims of different denominations and orientations and therefore have a less exclusionary attitude.

In the aftermath of September 11, an article about Yusuf was published in the British newspaper The Guardian (O’Sullivan 2001). The article tells of Yusuf's meeting with President Bush, where 'he advised Bush that the military term “Operation Infinite Justice” was blasphemous to Muslims”. Yusuf joined in singing 'God Save America'. In his speech outside the White House, Yusuf stated that "Islam was hijacked on that September $11^{\text {th }}$, 2001, on that plane, as an innocent victim” (ibid.). On 17 October, 2001, Yusuf was a guest of MBC, the Arabic-medium satellite channel based in London. When asked why he agreed to meet President Bush, he answered that he went in order to explain the Islamic position on the terrorist matter. He continued, saying that even the Prophet Moses went to speak with Pharaoh in a nice and decent way in an attempt to make him understand his point of view. By speaking in these religious terms, he legitimated his intervention religiously.

In Yusuf's case, we see that he suddenly became more 'American' in the time of crisis after September 11. Prior to the attacks on the US, Yusuf had often condemned America and the American way of life in a typical first stage manner. The article in The Guardian states that it was as though Yusuf has gone through 'a second, possibly more radical, conversion than the first from Christianity’ (ibid.). Yusuf is said to regret his ‘angry statements about Jews and America' and to be sorry for having said prior to 9/11 that “"a great, great tribulation was coming to America'. 
I attended one of Yusuf's speeches in London and it was obvious that he was affected by the September 11 attacks on the US. He dwelt on the fact that the alleged aeroplane hijackers were devout Muslims. His explanation for their behaviour was presented in Freudian terms, suggesting that these men 'were brought up in a loveless environment'. He went on to analyse 'religious madness' and stated that human beings should not push too far in their religiosity. He claimed that he had met people whose intense religious experiences had made their intellect and mental state suffer. Yusuf further discussed the importance of tolerance as part of his post-September 11 mindset. It is possible to consider Yusuf's 'second' conversion and his 'disappointment' with Muslims of certain orientations in relation to the stages new Muslims go through in their ongoing conversion process. Yusuf's previous approach to Islam, when he professed anti-American and separatist views, can be regarded as within the framework of the stage of 'zealotry', whereas his approach after the 9/11 event points to him being in the stage of 'disappointment' with Muslims. Moreover, from promoting an exclusionist view before $9 / 11$, he has been brought by this event to adopt a more inclusionary stance, particularly towards non-Muslims, in a model of stage three - 'acceptance'. However, Yusuf's approach to Islam is still based on the modal type of 'character', as he professes a traditional understanding of Islam, with the following of an Islamic law-school and a particular standard of moral conduct, as the way to salvation.

As many converts have affirmed, they start out being 'more royal than the king', but, having gone through various stages, end up coming back to their roots, and thus becoming Muslims of various European nationalities. This Muslim identity involves similar personalities and similar attitudes to those before the conversion, but with an added Muslim dimension. The development through stages may be the result of educational development, or personal development, or, in the case of Yusuf, a shocking event that brings about a change of perspective overnight. Yusuf's change can be regarded as a change from Muslim to 'American Muslim', with a distinct American message now included in his 'mature' understanding of Islam. 


\section{Yusuf Islam}

Another example of the conversion process in stages is the former pop-star Cat Stevens' navigation through the Islamic landscape. Stevens had his first success in 1966 and in the 1970s recorded hits such as 'Father and son' and 'Morning has broken'. Both songs point to the then Cat Stevens' search for a higher reality and in 1977 he converted to Islam. On his homepage he ascribes his conversion to the accident in which he nearly drowned in 1975 and relates that he promised God that he would work for him if he was saved. After converting to Islam, Stevens changed his name to Yusuf Islam; he sold his musical instrument and devoted his life to Islamic charitable and Islamic educational projects. Yusuf Islam did not perform music for many years. In the first stage of his conversion process, he rejected most of his former lifestyle and particularly his musical instruments, which he sold. He explains: 'There was a time when I listened to conservative voices in my Muslim community in London. They warned me of the dangers of sex, drugs and rock'n'roll. I maybe built up a wall which I now with pleasure will tear down” (Amster 2011).

In the pattern of 'zealotry' he seems to have been turning inwards into the Islamic fold, accepting rules and precepts revealed to him by born-Muslims as well as written in Islamic literature, such as that the use of musical instruments is harām (religiously prohibited). During the 1990s he started to sing Islamic songs (nashīd) accompanied by a drum, the only accepted instrument in Islamic law-school literature, and in 2000 he released the album 'A is for Allah', also accompanied only by a drum. In 2003, he released an album of his old songs, donating the earnings to the children of Iraq. In 2004, the Irish singer Ronan Keating released a new version of Cat Stevens’ 1970 hit 'Father and son', and for the first time Yusuf Islam performed publicly with musical instruments as he sang this song in duet with Keating. In 2006, he released a new album called 'An other cup' with musical instruments, and he is reported to have said: 'I feel right about making music and singing about life in this fragile world again.' (Jeffrey 2006).After the revolutionary upheavals in North Africa and the Middle East, Yusuf Islam released a single called 'My people' and for the first time in 
30 years began to perform in concerts that included both new and old songs. Interestingly enough, advertising posters use both his names, Cat Stevens and Yusuf Islam. This reference to his former stage name may be regarded in terms of the notion of 'turning back to himself', a common reference in this third stage (Roald 2004).

It seems obvious that Yusuf Islam's understanding of the Islamic view of musical instruments has changed during the course of his spiritual journey. This may be a result of his acquiring more knowledge of Islamic and more understanding of Islamic plurality; as many Muslims Sufi orders, for instance, use music as an expression of the spiritual quest for a higher reality and for encounters with the divine. His return may, however, also be the result of a change in attitude towards Islam. Many converts read a multitude of books in order to learn to be 'good' Muslims at the outset of their quest for Islamic truth and the books with which they come into contact often encourage a literal understanding of the Qur'an, Hadith and Islamic law. As their knowledge increases, they acquire an understanding that there are a multitude of interpretations of Islamic texts, as well as multiple ways of practising Islam. As many Islamic books take the socio-political view of Islam as a 'way of life', with no separation between religion and politics, it seems that many converts in the third stage of conversion tend to turn slightly towards a stance from which they see religion as more private, and religiosity as a matter of personal devotion rather than social manifestations. Yusuf Islam’s ‘turning back to himself' is thus to a certain extent build on a modal type of 'personality' rather than of 'character'.

Both Yusuf Islam’s and Hamza Yusuf's Islamic development can be seen as illustrating the developing conversion process, in which one sets out rejecting his or her former religious and cultural positions and ends up in a less 'zealous' state of mind, coming 'back to oneself within an Islamic framework’. 


\section{The fourth stage: 'secularization'}

Whereas converts in the three first stages to a greater or lesser extent regard 'Islam as a way of life', a comprehensive system dealing with all aspect of human life, the convert at the fourth stage tends to adopt an approach to religion as wholly private, i.e., the secular view that religion and politics should be separated. Moreover, an approach to religion as private tends to lead the person to choose parts of the religious message rather than following a set of ready-made codes of conduct, as commonly implied in the idea of 'Islam as a way of life'.

With Susman's modal type theory in mind, it is possible to see this fourth stage of the conversion process as a manifestation of the modal type of 'personality' overtaking that of 'character', which was the modal type of the first, second and to a great extent even the third stages of the conversion process. Western converts have generally been previously socialized into the cultural modal type of 'personality’. As they embrace Islam, they are forced into the modal type of 'character', as they need to follow a standard form of conduct in order to be 'good Muslims'. As we have seen in the third stage of the conversion process, the stage of 'acceptance', many converts tend to regard themselves as having ‘turned back to themselves’ after going through stages in which rejection of their former cultural background was a main element. The modal type of 'personality' is still influential even in the third stage of the conversion process, as we also saw in the case of Yusuf Islam, but it is in the fourth stage that it 'personality' is reinforced in the convert's understanding and practice of Islam.

The converts at this 'secularized' stage of the conversion process are critical towards bornMuslims, adopting an attitude resembling that of converts at the second stage. The difference, however, is that, while most converts at the second stage still believe that 'Islam is a way of life', the converts at the fourth stage tend to be critical even of this Islamic ideal. This is particularly due to their disappointment with the political situation in Muslim countries, the huge problems within Muslim communities in Western countries, and the recent link between Islam and terrorism. 
Moreover, converts at this stage of the conversion process tend to be critical to the idea of Islam as 'the only truth'. While most converts at the third stage realize that there are many Muslims who have a different view from their own, they would still see their own understanding of Islam as the only 'true' understanding. Converts at the fourth stage, however, have a greater awareness of the possibility of understanding the sacred texts in various ways and, as a result, they consider the possibility of being a Muslim without necessarily having to accept every detail in the Qur'an and Sunna. Some may even consider the Islamic texts in the context of seventh-century Arabia, and search for Islamic guiding principles rather than specific laws and regulation on their path to salvation.

An example of converts at the fourth stage is the American convert Aminah Wadud. Wadud embraced Islam in the 1970s and, from her own statements, it seems she has gone through the conversion stages in a subsequent order. In New Internationalist she writes:

I converted to Islam during the second wave of feminist movement in the 1970s. I saw everything through a prism of religious euphoria and idealism. Within the Islamic system of thought I have struggled to transform idealism into pragmatic reforms as a scholar and activist. And my main source of inspiration has been Islam’s own primary source - the Qur'an. (Wadud 2002)

She saw 'everything through a prism of religious euphoria and idealism', a typical 'first stage' phenomenon. However, it is the statement that the Qur'an has been her 'main source of inspiration' that indicates her turn towards a private and secularized Islamic world-view. Wadud's feminist approach has obviously led her to stay aloof from the Hadith and legal literature, as these texts are to a great extent gender biased. This position is even apparent in her famous book Women in the Qur'an, first published in 1992. It seems that although she admits that the Qur'an does contain problematic texts concerning gender issues, these texts can, like biblical gender biased texts, be reinterpreted hermeneutically in order to fit a gender equality position (Wadud 1999). The notion of 
Islam as a comprehensive system of life builds on the Qur'an, the Sunna, and the scholarly interpretation of these sources. Except for particular detailed verses on inheritance issues, the Qur'an contains few detailed rules and regulations, but rather provides the reader with general guidelines on moral and ethical issues. Even some of those Muslims who regard Islam as a 'way of life' might challenge the gender roles set out by the Islamic law-schools. Wadud's emphasis on the Qur'an alone indicates that she follows a private religiosity approach, choosing parts of the religious message, and a secular worldview that places religion in the sphere of private life.

Wadud's rebellion against traditional gender patterns in the Muslim world further indicates a turning away from the traditional Islamic pattern of Islam as 'a way of life' into a more secularized worldview. Moreover, her rebellion reflects the shift from 'character', with its following of a standard form of conduct, to 'personality', with an emphasis on her own 'personal needs and interests' (Susman 1979, 217). In March 2005, she led a Muslim congregation of men and women in prayer in St John's Cathedral in New York. Traditional Islamic regulations do not permit a female imam to lead a mixed congregation and, moreover, by praying in a church she indicates an inclusive attitude towards other religions - an attitude more common among Muslims who adopt a private religiosity than among Muslims with ‘a way of life’ approach to Islam.

In January 2007, I met some converts I had interviewed previously in 2000. Many of them told a similar story of moving towards a different stage from the one at which they had been seven years before. The story of Anita from Sweden is an example of this journey towards a fourth stage in the conversion process. In 2000, Anita married a born-Muslim from North Africa and she often referred to the ideal Islamic state in contrast to the situation in the Muslim world and of Muslim communities in Sweden. By 2007, however, she was divorced and described herself as a 'secularized’ Muslim, explaining “'secularised” as meaning being a "bad Muslim”'. 'I do not pray or fast and I keep aloof from Muslims as they represent negativity and pessimism to me,' she states. She no longer believes in the ideal of an Islamic state, 'as', she explains ironically, 'which Muslim could possibly be a 
sound Islamic leader today’. At the same time, Anita says that she is still a Muslim and she believes in God, although she believes that human beings have 'changed the message of God'.

I discussed the three stages of the conversion process with her and she exclaimed, 'Is there not a fourth stage - in which I am?' She spoke of the difficulties of her life after she became a Muslim and said that these experiences had influenced her view of Islam today. She embraced Islam at the age of 22 and immediately married a born-Muslim. After three years she divorced him, and she had a difficult time as she felt other Muslims were critical to her for divorcing her husband. 'He was so difficult,' she exclaimed. 'I had to obey him in everything and I had no saying in this marriage.' However, she also admitted that she was too 'weak', hardly standing up to her ex-husband, but she explained that this was because she wanted to be a 'good' Muslim. 'I did not really know what a “good” Muslim was and I believed my husband when he said that a Muslim wife has to obey her husband.' After her divorce, she married a man from Algeria, and although he was less harsh and she had a more relaxed life with him, she also decided to divorce him. 'I do not believe in Swedish women marrying, particularly first generation, Muslim immigrant men,' she said, and went on:

We, the Swedish women and first generation Muslim immigrants, have such different backgrounds and we converts do not always know what is right or wrong according to Islam. Men with Muslim cultural background have a more pushy way and that makes Swedish female converts give in and accept oppressing behaviour from their husbands. I know so many converts who have difficult marriages but they accept to stay because of the children. When convert women meet they mostly discuss their 'difficult' husbands and I am so fed up with this.

Her view of Islam had changed radically only the years. She pondered:

I know intellectually that I cannot judge Islam by what Muslims do and say. This is what I always hear from Muslims. But If Islam is the right religion should this not be reflected inn the adherents, by making them act in a right way? 
Anita faced a sort of a life crisis after her second divorce. With no husband to limit her questioning of Islamic ideas, she said that she had ended up in a 'no man's land':

At first after the divorce I tried to create my own Islamic identity according to what I believe is true Islam, but I ended up with the feeling of being alone on an isolated island. I started to wonder what was actually true in the Islam I had learnt about, and to be honest, I do not really know. Everything is so ambiguous. When I hear the Qur'an being recited it is so beautiful and so right. But there is something that does not make sense. There is something in my way of thinking that makes it difficult to accept everything in the Qur'an. And I have no right to question because that makes me a kāfir [unbeliever] in the eyes of the Muslims. The Qur'an says, for instance, that a man can hit his wife. For me this is so wrong and so absurd; I cannot accept that anyone can hit anybody. I do not believe it is right but I have to say that it is right, otherwise other Muslims will judge me. And Muslims have a tendency to judge other people. Muslims see everything in black or white; either you are a 'good' Muslim and accept the whole package or you doubt something and you are condemned.

She continued:

It was the same when I was a practising Muslim. At that time it was the salafists who always condemned those who did not believe or act according to their ideas. I was never a 'real' Muslim anyway. I have learnt one thing; to always be careful with people who claim they own the truth.

Now I feel I am an open wound inside. I can sense that I am not at the end of my journey yet, but at the moment I do not have the power to continue.

Anita’s story and her statements reflect the shift from the modal type of 'character' to 'personality'. After she divorced, she did not have anybody to control her Islamic behaviour or to influence her to behave in a more Islamic fashion, and her background as socialized into a 'personality culture' came 
back to her. Furthermore, Anita used previously to socialize with other converts, but since she started to question Islamic precepts she prefers to be alone rather than with her former convert friends. Her turning away from the convert community reinforced the lack of control by a 'character culture' with its stress on moral conduct. Her questioning has made her develop in a different direction from them and she feels that they are not developing at all, remaining in the same way of thinking as they have had for 20 years. She states:

I was brainwashed. Now, I can often remember how I was thinking and I am surprised or even embarrassed that I could think in such a manner. I watched a TV-programme the other day, about a Christian sect and suddenly I realized that it was the same way with us in Islam. All the rules were there in order to control and isolate us from the rest of society. For instance, the headscarf; it is so meaningless - I really see no point in it. And the other rules on social relations and foodstuff; they do not function at all in this society. Today I am a believer but do not follow religious rules.

Anita's journey from being a practising believer to just a 'believer', as she calls herself, can be considered to be within the paradigm of becoming a private religious person and changing from the modal type of 'character' to that of 'personality'. It is obvious from Anita's words that her conversion process has not yet come to an end, if it ever can come to end, but at the stage she is in now, she does not believe Islam to be a way of life or a socio-political system that governs the private and the public sphere alike. She believes in God, but she cannot accept the whole package of Islam as it is understood by many Muslims today. At present, she is in a stage of 'secularization', believing that religion should be separated from public life, partly because there is a lack of leadership but also because there is a mismatch between the understanding of the 'Islamic ideal' and life as she experiences it. 


\section{Reflections}

The conversion process in stages as experienced in Islam seems to be a common factor in conversion to various religions. Rambo’s research deals mainly with conversion to and between Christian congregations. However, as his study depends on psychological research, it is appropriate to assume that some of his proposed stages resemble those many converts go through in the post-conversion period. Schindler's observations of his fellow Danish converts to Catholicism going through the stages of 'enthusiasm' through 'boredom' to a 'mature' religiosity echo the Muslim convert stages noted above of 'zealotry’, ‘disappointment', and ‘acceptance’. However, as modern understandings of Catholicism, in contrast to many modern interpretations of Islam, do not claim that the Catholic system is a comprehensive way of life, the stage of 'secularization' seems to be an aspect of modern Catholicism that is inherent from the beginning, rather than being a fourth stage in conversion as may be observed in Muslims’ conversion processes.

The rejection of the converts' former cultural and religious sphere is an important aspect of the first Muslim conversion stage of 'zealotry'. This rejection may be less expressed among converts to other religions than Islam because the particular negative attitude towards Islam in the Western world today has created a 'minority thinking' and an emphasis on identity politics in Muslim communities, with an 'us-and-them' approach towards majority society. Converts thus enter into a pattern of rejection of the Western system. This is less explicitly expressed in sufi communities, which do not adhere strictly to the Islamic law-schools.

The second stage of the Muslim conversion process is the stage of 'disappointment', when converts realize that Muslims in general do not live up to the sublime ideal of 'Islam'. It is particularly at this stage that many Muslim converts tend to start to socialize mainly with other converts rather than with the born-Muslim community. The converts' frustration with born-Muslims is seen in the British convert Michael Young’s expression: ‘To be honest, I remain in Islam very much in spite of - and not because of - my experience with [born] Muslims’ (Young 2001). 
Many converts, particularly women in Scandinavia, feel that born-Muslims see them as 'figure-heads’ (Roald 2004, 279). The negative image of Islam in the Western world makes bornMuslims see converts' acceptance of Islam as a confirmation of the 'truth of Islam' and in social gatherings with non-Muslims, Western female converts are brought forward as trophies. However, as converts starts to gain knowledge and often interpret Islam in terms of their own cultural background, they may experience a certain antagonism from the born-Muslim community. The convert reaction is then to form their own Islamic space, consisting of new Muslims and perhaps some second-generation Muslims. At the later stages of the conversion process, converts' social space is thus often separate from that of born-Muslims.

ReferencesAllievi, Stefano. 2006. The shifting significance of the halal/haram frontier: Narratives on the hijab and other issues. In Women embracing Islam: gender and conversion in the West, ed. K. van Nieuwkerk, 120-49. Austin: University of Texas Press.

Amster, H. 2011. I Moses fotspår (In the footsteps of Moses). Svenska Dabladet, 24 April. http://www.svd.se/kultur/i-moses-fotspar_6113037.svd (accessed 18 February 2012).

Berger, P. and T. Luckman. 1967. The social construction of reality. New York: Anchor. Bukhari, al-. n.d. Șaḥịh al-Bukhārī, system al- 'Alamī. Jedda: Company Sakhr al-Alami. CDROM.

Channel Four. 2007. Undercover mosque. http://video.google.com/videoplay?docid=2515587181120245843 (accessed 18 February 2012)

Coser, Lewis A. 1977. Masters of sociological thought: ideas in historical and social context, $2^{\text {nd }}$ edn. New York: Harcourt Brace Jovanovich. 
Gerholm, T. 1988. Three European intellectuals as converts to Islam: Cultural mediators or social critics? In The new Islamic presence in Western Europe, ed. Tomas Gerholm and Yngve Georg Lithman, 263-77. London: Mansell.

Haddad, Yvonne Yazbeck. 2006. The quest for peace in submission: reflections on the journey of American women converts to Islam. In Women embracing Islam. gender and conversion in the West, ed. K. van Nieuwkerk, 19-47. Austin: University of Texas Press.

Hamberg Eva. 1999. International migration and religious change. In Towards a new understanding of conversion, ed. Ulf Görman, (Religio 50). 23-37. Lund: University of Lund.

islamictube.net. 2007. Response to Dispatches. islamictube.net/view_video.php?viewkey=7304975ccb23337bb576 (accessed 18 February 2012).

James, William. 1903. The varieties of religious experience. The Gifford Lectures 19011902. New York: Longmans, Green, and co.,

Jeffrey, Don. 2006. Yusuf Islam, Once Cat Stevens, Plans Comeback Album (Update2) Bloomberg 7 September.

http://www.bloomberg.com/apps/news?pid=newsarchive\&sid=aaQ27CqEsmSA\&refer=muse (accessed 28 February 2012)

Keller, Nuh Ha Mim. 1991. The reliance of the traveller. Dubai: Modern Printing Press.

Köse, Ali. 1996. Conversion to Islam: a study of native British converts, London: Kegan Paul International.

Lofland, John and Rodney Stark. 1965. Becoming a world-saver: a theory of conversion to a deviant perspective. American Sociological Review 30, no. 6: 862-75.

Malik, Michael A. n.d. Islam is wonderful, but I can’t stand the Muslims. http://www.islamfortoday.com/malik01.htm (accessed 20 February 2012). 
Månsson, Anna. 2002. Becoming Muslim: meanings of conversion to Islam. Lund:

Department of Ethnology, Lund University.

Murad, Abdal-Hakim. 1997. British and Muslim?

http://www.islamfortoday.com/murad05.htm (accessed 23 February 2012)

Nock, A.D. 1998 (1933). The old and the new from Alexander the Great to Augustine of Hippo. Baltimore, MD: John Hopkins University Press.

Østberg, Sissel. 2006. Islamic nurture and identity management: the lifeworld of Muslim children and young people in Norway. In International handbook of the religious, moral and spiritual dimensions in dducationed. M. De Souza, K. Engebretson, G. Durka, R. Jackson, A. McGrady, 501-12. New York/Heidelberg: Springer.

O’Sullivan, J. 2001. If you hate the West, emigrate to a Muslim country. The Guardian, 8 October. http://www.guardian.co.uk/world/2001/oct/08/religion.uk (accessed 18 February 2012).

Otterbeck, Jonas. 1999. Skolan, islam och muslimer. In Blågul islam? Muslimer i Sverige, ed. David Westerlund. 157-74. Nora: Nya Doxa.

Philips, B. (Abu Aminah). 1990. The fundamentals of tawheed: Islamic monotheism. London: Dar al-Tawheed.

Poston, Larry. 1992. Islamic da'wah in the West: Muslim missionary activity and the dynamics of conversion to Islam. New York, Oxford: Oxford University Press.

Rambo, Lewis R. 1993. Understanding religious conversion, New Haven, CT: Yale University Press.

Rambo, Lewis R. and Charles E. Farhadian. 1999. Converting: stages of religious change. In Religious conversion, ed. Christopher Lamb and M. Darrol Bryant, 22-34. London: Cassell.

Roald, Anne Sofie. 2001. Women in Islam: the Western experience. London: Routledge. 
Roald, Anne Sofie. 2004. New Muslims in the European context: the experience of Scandinavian converts. Leiden: Brill.

Roald, Anne Sofie. 2006. The shaping of a Scandinavian 'Islam': converts and gender equal opportunity. In Women rmbracing Islam: gender and conversion in the West, ed. K. van Nieuwkerk, 48-70. Austin: University of Texas Press.

Starbuck, Edwin. 1901. The psychology of religion: an empirical study of the growth of religious consciousness. $2^{\text {nd }}$ ed. London: Scott.

Susman, Warren I. 1979. 'Personality’ and the making of twentieth century culture. In New directions in American intellectual history ed. John Higham and Paul K. Conkin, 21226. Baltimore, MD: John Hopkins University Press.

Umm Zaid, S. 2003. Convertitis - or the case of the insta-scholar'. http://www.islamfortoday.com/ummzaid02.htm (accessed 20 February 2012). van Nieuwkerk, Karin, ed. 2006. Women embracing Islam: gender and conversion in the West. Austin: University of Texas Press.

Wadud, A. 1999 (1992). Qur'an and woman: rereading the sacred text from a woman's perspective. New York: Oxford University Press.

Wadud, A. 2002. A’ishah’s legacy. New Internationalist 345. http://www.newint.org/features/2002/05/01/aishahs-legacy/ (accessed 20 February 2012.

Werner, Yvonne Marie. 2010. Catholic mission and conversion in Scandinavia: some reflections on religion, modernisation, and identity construction. Scandinavian Journal of History 35,no. 1: 65-85.

West, Rebecca. 1933. St Augustine, New York: D. Appleton \& Co.

Young, Michael. 2001. Frustration of a convert. Q-News, June.

\section{Notes}


${ }^{1}$ From 1999 to 2003, I conducted a study on Swedish, Danish, and Norwegian converts to Islam. I handed out 130 questionnaires and received 116 answers (84\% men and 16\% men). In addition, I conducted in-depth interviews with 32 converts (23 women and 9 men) from the group of respondents. I also visited and had discussions with converts and Muslims in general in other European countries and in the USA in the 1980s, 1990s, and in the early years of the twenty-first century.

The study was part of a wider research project at Lund University, Sweden, on converts in general: The researchers dealt with conversion to Catholicism and to secularism, the conversion theme in literature, etc. 